\title{
Haul-out pattern of itinerant male Antarctic fur seals (Arctocephalus gazella) at Laurie Island, South Orkney Islands
}

\author{
Alejandro R. Carlini, Gustavo A. Daneri, \\ Ricardo Casaux, María E. I. Márquez
}

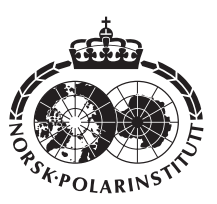

The seasonal haul-out pattern of itinerant male Antarctic fur seals (Arctocephalus gazella) was determined by regular counts at Mossman Peninsula, Laurie Island, South Orkney Islands, from 1996 to 2005. Small numbers of animals began to arrive at the beach in late December/early January (mean date 28 December \pm 15 days, $n=10$ ). Peak numbers of animals ashore changed considerably between seasons. In 1996, 1998 and 2001, peak numbers were registered in March (6/3, 18/3 and 6/3, respectively). Numbers peaked in 1997, 1999 and 2005 at the end of January/beginning of February (26/1, 2/2 and 28/1, respectively). In 2000, 2002, 2003 and 2004 peaks were registered in the third week of February $(15 / 2,22 / 2$, $14 / 2$ and 20/2, respectively). Peaks in numbers of seals ashore also varied between years, being minimum during 2001 (2531 individuals) and maximum during 2006 (16610 individuals). In March 1998 the coasts of Laurie Island were surveyed by navigating inflatable boats near the shoreline; 18 haul-out places were identified. The big differences in peak numbers, as well as in the dates of peak events among years, suggest that local conditions could have an effect on the numbers of animals hauled out in a given year. It may therefore be difficult to predict trends from summer censuses in non-breeding places.

A. R. Carlini, R. Casaux \& M. E. I. Márquez, Depto. de Ciencias Biológicas, Instituto Antártico Argentino, Cerrito 1248, C1010 AAZ Buenos Aires, Argentina, acarlini@dna.gov.ar; G. A. Daneri, División Mastozoología, Museo Argentino de Cs. Naturales "B. Rivadavia”, Av. Angel Gallardo 470, C1405 DJR Buenos Aires, Argentina.

Antarctic fur seals (Arctocephalus gazella Peters, 1875) were subjected to an extensive commercial harvest and nearly exterminated during the 19th and early 20th centuries (Bonner 1968). Since the cessation of sealing a substantial recovery of the population has taken place from small remnant breeding groups located around South Georgia and Bouvetøya (Bouvet Island) (Bonner 1968; Payne 1977; Boyd 1993; Wynen et al. 2000). At present, the main breeding locations are at Bird Island and at the western end of South Georgia
(Boyd 1993), although breeding colonies have been re-established throughout the Scotia Arc and elsewhere (Bengtson et al. 1990).

There are no important breeding places in the South Orkney Islands, probably because the archipelago as a whole has too short an ice-free summer to allow successful breeding (Kightley \& Caldwell 1982). Laws (1981) identified breeding colonies at Monroe Island, Gosling Islands and Michelsen Island, comprising around 100 pups. Additionally, Kightley \& Caldwell (1982) 


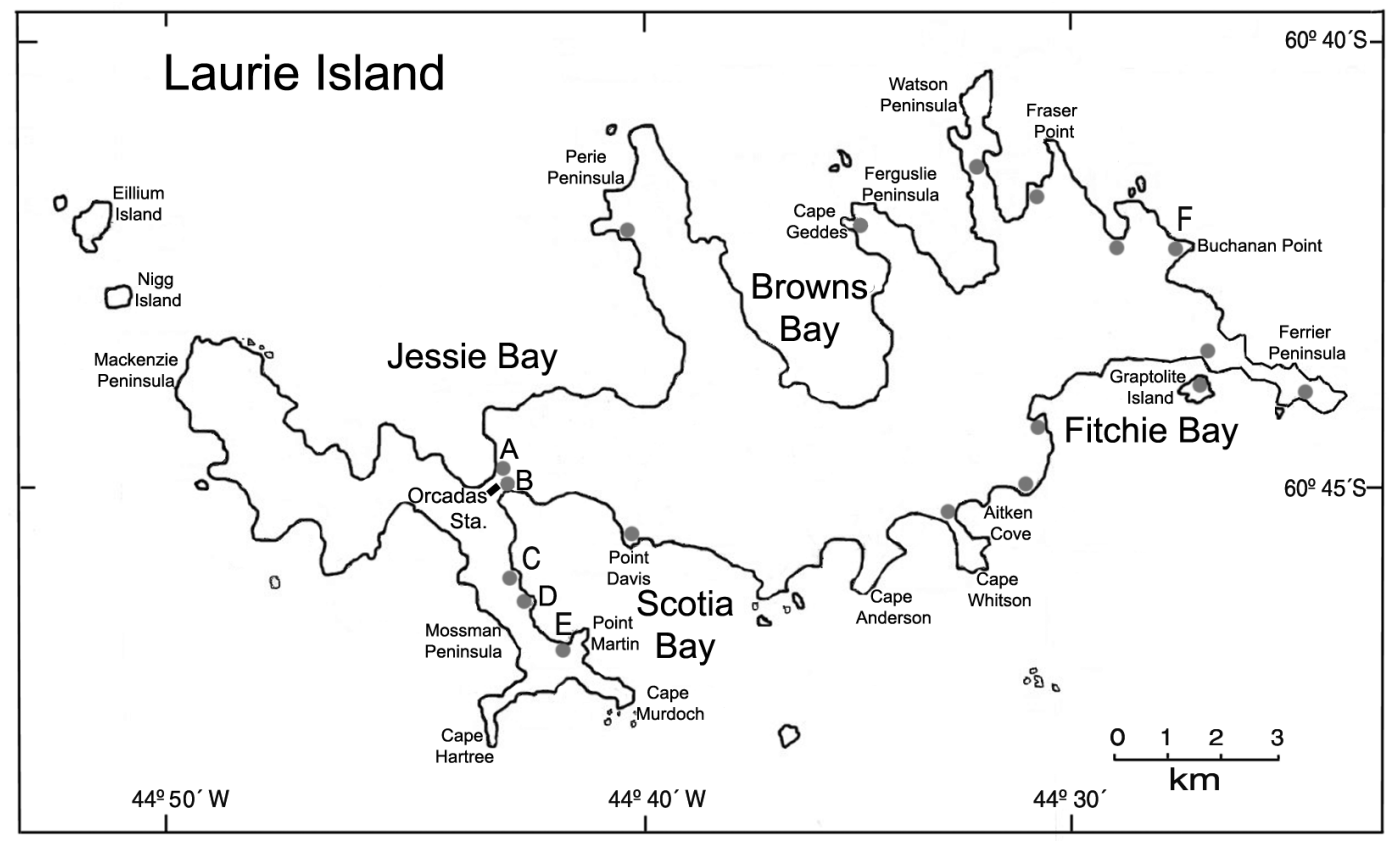

Fig. 1. Haul-out places (grey dots) of itinerant Antarctic fur seals (Arctocephalus gazella) in March 1998 at Laurie Island, South Orkney Islands. A-E mark sites where weekly counts were made.

reported the first birth on Signy Island in February 1987. Total pups born in the archipelago were recently estimated to be less than 1000 (SCAR Expert Group on Seals 2004). No breeding groups have been reported at Laurie Island and only four births have been recorded there. However, an important group of non-breeding adult and subadult males is present during the summer at this location (Vergani \& Coria 1989).

The work on which this paper is based was carried out at Laurie Island over 10 consecutive years. The study presents information on the haulout pattern of itinerant male Antarctic fur seals at Mossman Peninsula and provides the results of the first survey of the whole coast of the island.

\section{Materials and methods}

The study was carried out at Mossman Peninsula, Laurie Island $\left(60^{\circ} 45^{\prime} \mathrm{S}, 44^{\circ} 43^{\prime} \mathrm{W}\right)$, South Orkney Islands, from 1996 to 2005 (Fig. 1). Antarctic fur seals were counted weekly throughout the year by two observers on foot along the approximately $4 \mathrm{~km}$ of coast between the Argentinean Orcadas Station and Point Martin (sites A, B, C, D, E on Fig. 1). The same observers who counted the animals in one year trained, for about one month, two other observers for the following year. When groups had over 3000 seals, which generally occurred in site $\mathrm{C}$ for some seasons, three independent counts were made from a cliff and the average value was calculated.

Animals were not sorted into age classes but they were mainly adult and sub-adult males. Between 6 and 13 March 1998 the coasts of Laurie Island were surveyed by navigating inflatable boats near the shoreline to identify additional haul-out places.

Since animals began to arrive in December, reports for a given year in this work include data from December of the previous year (i.e. the number of seals reported for 1996 includes December 1995).

\section{Results and discussion}

Small numbers of animals began to arrive at the beach in late December/early January (mean date 28 December \pm 15 days, $n=10$ ), and numbers started to increase from the second week 


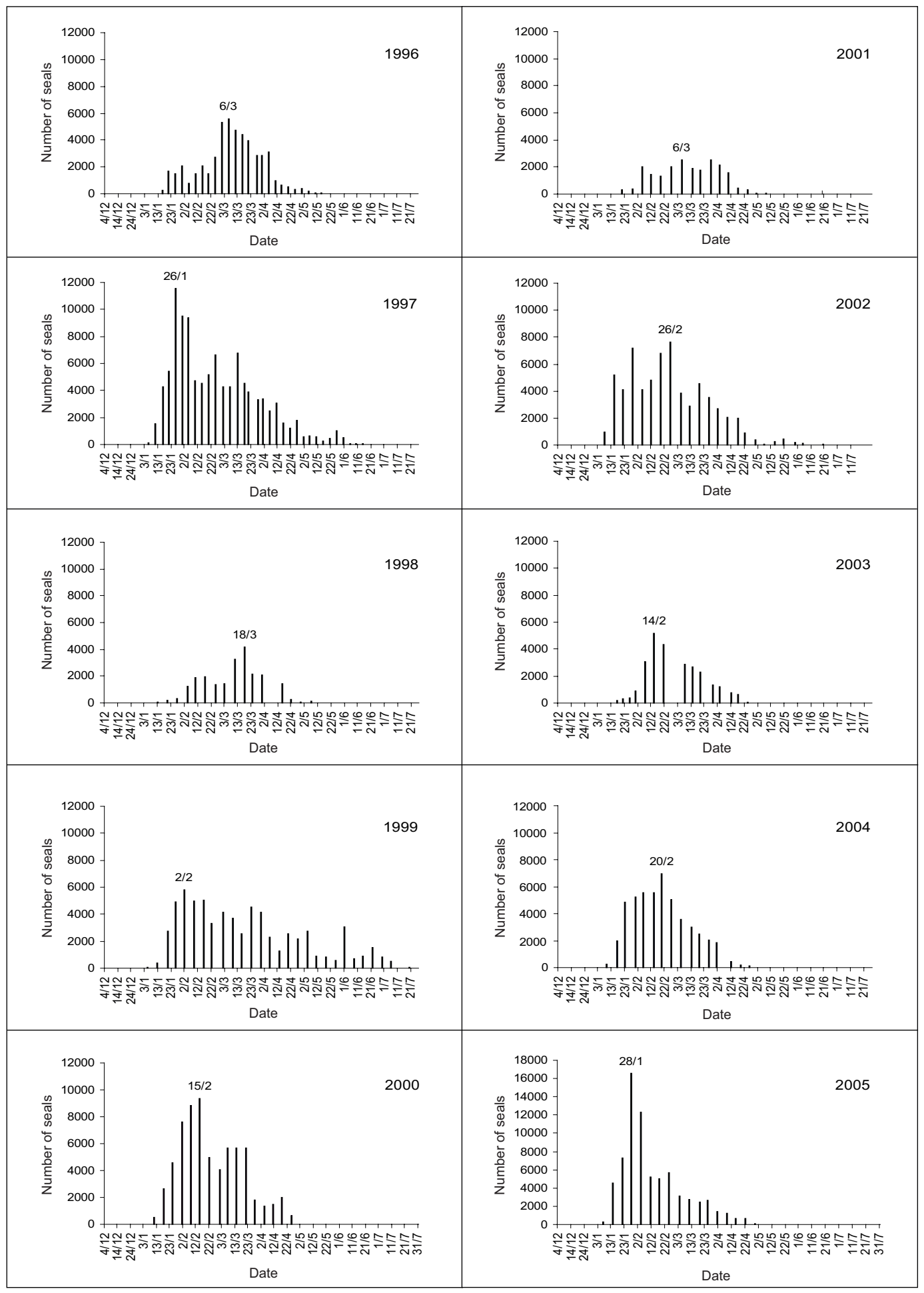

Fig. 2. Changes in the number of itinerant Antarctic fur seals (Arctocephalus gazella) present on the study beach at Laurie Island from 1996 to 2005. Reports for a given year include data from December of the previous year. 


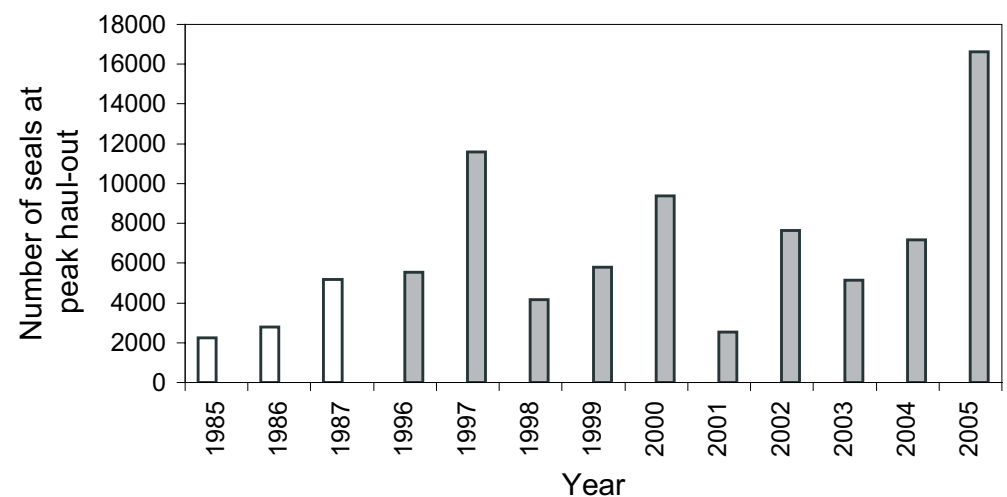

Fig. 3. Numbers of Antarctic fur seals (Arctocephalus gazella) at peak haul-out. Data for 1985-87 from Vergani \& Coria (1989); data for 1996-2005 from this study. of January (Fig. 2). The peak number of animals ashore varied among seasons (Table 1, Fig. 2). In 1996, 1998 and 2001, peak numbers were registered in March (6/3, 18/3 and 6/3, respectively). In 1997, 1999 and 2005 numbers peaked at the end of January/beginning of February (26/1, $2 / 2$ and 28/1, respectively). In 2000, 2002, 2003 and 2004 peaks were registered in mid-February $(15 / 2,22 / 2,14 / 2$ and $20 / 2$, respectively). The haul-out period for non-breeding Antarctic fur seals was also reported for Heard Island by Page et al. (2003), who observed that the number of sub-adult and adult males increased markedly from late January, with the highest numbers registered between 23 February and 9 March. Similarly, at Signy Island (South Orkney Islands) the annual summer immigration amounted to 20500 individuals, with peak numbers also occurring in February (Smith 1997), while at Marion Island,

Table 1. Dates and numbers of itinerant Arctocephalus gazella at peak haul-out from 1996 to 2005 at Mossman Peninsula, Laurie Island.

\begin{tabular}{lcc}
\hline \multirow{2}{*}{ Year } & \multicolumn{2}{c}{ Main peak event } \\
& Date & Numbers \\
\hline 1996 & 6 March & 5559 \\
1997 & 26 January & 11577 \\
1998 & 18 March & 4163 \\
1999 & 2 February & 5778 \\
2000 & 15 February & 9368 \\
2001 & 6 March & 2531 \\
2002 & 26 February & 7635 \\
2003 & 14 February & 5160 \\
2004 & 20 February & 7164 \\
2005 & 28 January & 16610 \\
\hline
\end{tabular}

maximum numbers of adult and sub-adult males occurred during the autumn moulting peak in March (Kerley 1983). The dates of peak numbers in most years at Laurie Island (February-March) are similar to those found at the above-mentioned localities, which would be accounted for by animals coming ashore during their moulting period. However, in some years $(1997,1999,2005)$ peak numbers of animals ashore occurred in late January/early February, although in these "atypical" years a second lower peak followed in February-March (Table 1, Fig. 2). Between August and November, in some of the years, there were very few animals on the beach. For this period, maximum numbers occurred in October in 1996, 2001, 2003 and 2004 (37, 103, 27 and 34 fur seals, respectively), but in August in 1999. No fur seals were observed in 1997, 1998, 2000 or 2002 for the same period.

Total numbers of animals ashore at Laurie Island at peak haul-out varied enormously among years, with lowest numbers in 2001 (2531 animals) and a maximum in 2005 (16610 animals) (Fig. 3). Such a variation in seals' numbers could be related to an ocean wide event such as El Niño-Southern Oscillation (ENSO). ENSO has a profound effect on the weather and oceanic conditions across the tropical Pacific, where it has its origin. It has been suggested that the effects of ENSO might be transmitted from the tropical Pacific Ocean to the Antarctic (Turner 2004). This could cause changes in physical environmental variables, finally affecting the numbers of animals observed. We could not find a clear connection between the number of seals at peak haul-out and ENSO. El Niño events $(1997 / 1998$ and $2002 / 2003)$ or La Niña events (1998/1999 and 2000/2001) involved seasons with 
similar numbers of seals at Laurie Island at peak haul-out (Table 1, Fig. 2).

Considering the previous census in the area (Vergani \& Coria 1989), it seems likely that there has been an increase in the numbers of Antarctic fur seals that haul out on the beaches in the study area (Fig. 3). However, the big inter-annual differences in numbers together with the variations in the peak dates, support the idea that local conditions, with their potential effects on food availability in the area, could have an effect on the numbers of animals hauled out in a given year. It may therefore be difficult to predict trends from summer censuses in non-breeding places.

A total of 18 haul-out places were identified from the survey of the Laurie Island coast in March 1998 (Fig. 1). Because observers were not able to land to count seals, we lack accurate estimates of animals at these sites. Nevertheless, it was possible to observe that site $\mathrm{C}$ at Mossman Peninsula shelters the biggest haul-out place at Laurie Island, while the second largest concentration of animals was identified at site F (Fig. 1).

Fur seals at Laurie Island are probably immigrants from South Georgia (Kightley \& Cadwell 1982), which is home to the largest fur seal population and accounts for around $95 \%$ of total pup production for the species (Boyd 1993), with the current population estimated at over three million individuals (Barlow et al. 2002). Available data from South Georgia indicate an annual increase in pup production of $16.8 \%$ from 1957 to 1972 (Payne 1977) and 9.8\% from 1976 to 1990, as well as an expansion of the breeding range (Boyd 1993). It has been suggested that a possible reason for the decline in the annual increase in the South Georgia population is that emigration is taking place from the traditional breeding sites, some of which have reached their capacity (Boyd 1993). The South Orkney Islands are similar to South Georgia in that high densities of krill can be found nearby (Everson \& Goss 1991; Kasatkina et. al 1997). Availability of krill is a critical factor in determining breeding locations, since fur seals depend on rich localized food resources, especially during lactation (Costa 1991). In spite of this, only four pups were born at the study site on Laurie Island over the 10 -year study period, suggesting that the south coasts of Laurie Island are not suitable breeding areas for the species, probably because they are often covered by ice until December. Coincidentally, a survey of Antarctic fur seals in the South Shetland Islands indi- cated that no pupping sites were located on the southern coasts of these islands along the Bransfield Strait (Bengtson et al. 1990). According to these authors, the absence of pups on these coasts would suggest that newly occupied pupping sites may be vulnerable to disturbance (e.g. human, climatic factors) until a traditional pupping site is established and the rookery has become sufficiently large and socially stable to persist and grow. This explanation would fit well to the phenomenon observed at Laurie Island.

Acknowledgements.-We would like to express our gratitude to the staff of the Administración de Parques Nacionales: R. Cerda, S. Vellido, E. Luoni, O. Jensen, A. Georgópulos, C. Quintana, R. Zalazar, M. Calvi, R. Cerdá, M. Gray, G. Willink, A. Seuferheld, A. Sanchez, F. Ferioli, G. Porro, G. Sanchez, G. Carreras, P. Rosso, A. Dalmasso, R. Amado, A. Beati, D. Saad and E. Rombola for field assistance. We thank the members of the Orcadas Station for their logistic support. We want to thank two anonymous reviewers for their helpful comments on the manuscript.

\section{References}

Barlow, K. E., Boyd, I. L., Croxall, J. P., Reid, K., Staniland, I. J. \& Brierley, A. S. 2002: Are penguins and seals in competition for Antarctic krill at South Georgia? Mar. Biol. 140, 205-213.

Bengtson, J. L., Ferm, L. M., Härkönen, T. J. \& Stewart, B. S. 1990: Abundance of Antarctic fur seals in the South Shetland Islands, Antarctica, during the 1986/87 austral summer. In K. Kerry \& G. Hempel (eds.): Antarctic ecosystems: ecological change and conservation. Pp. 265-270. Springer: New York.

Bonner, W. N. 1968: The fur seals of South Georgia. Br. Antarct. Surv. Sci. Rep. 56.

Boyd, I. 1993: Pup production and distribution of breeding Antarctic fur seals (Arctocephalus gazella) at South Georgia. Antarct. Sci. 5, 17-24.

Costa, D. P. 1991: Reproductive and foraging energetics in pinnipeds: implications for life history patterns. In D. Renouf (ed.): Behaviour of pinnipeds. Pp. 300-344. London: Chapman \& Hall.

Everson, I. \& Goss, C. 1991: Krill fishing activity in the southwest Atlantic. Antarct. Sci. 3, 351-358.

Kasatkina, S. M., Shnar, M. I., Polischuk, M. I., Abramov, A. M. \& Sushin, V. A. 1997: Assessment of krill flux factors in waters of the South Orkney Islands during summer 1996. CCAMLR Sci. 4, 195-204.

Kerley, G. I. H. 1983: Comparison of seasonal haul-out patterns of fur seals Arctocephalus tropicalis and A. gazella on subantarctic Marion Island. S. Afr. J. Wildl. Res. 13, 71-77.

Kightley, P. J. \& Caldwell, J. R. 1982: The first record of a fur seal birth on Signy Island, South Orkney Islands. Br. Ant- 
arct. Surv. Sci. Rep. 51, 287-289.

Laws, R. M. 1981: Seal surveys, South Orkney Islands, 1971 and 1974. Br. Antarct. Surv. Bull. 54, 136-139.

Page, B., Welling, A., Chambellant, M., Goldsworthy, S. D., Dorr, T. \& Van Veen, R. 2003: Population status and breeding season chronology of Herd Island fur seals. Polar Biol. 26, 219-224.

Payne, M. R. 1977: Growth of a fur seal population. Philos. Trans. R. Soc. Lond. B 279, 67-79.

SCAR Expert Group on Seals 2004: Status of stocks. Tromsø. Accessed on the internet at www.seals.scar.org/pdf/ statusofstocs.pdf.

Smith, R. I. L. 1997: Impact of an increasing fur seal population on Antarctic plant communities: resilience and recov- ery. In B. Bataglia et al. (eds.): Antarctic communities, species, structure and survival. Pp. 432-436. Cambridge: Cambridge University Press.

Turner, J. 2004: The El Niño-Southern Oscillation and Antarctica. Int. J. Climatol. 24, 1-31.

Vergani, D. F. \& Coria, R. 1989: Increase in numbers of male fur seals Arctocephalus gazella during the summerautumn period at Mossmann Peninsula (Laurie Island). Polar Biol. 9, 487-488.

Wynen, L. P., Goldsworthy, S. D., Guinet, C., Bester, M. N., Boyd, I. L., Gjertz, I., Hofmeyr, G. J. G., White, R. W. G. \& Slade, P. R. 2000: Postsealing genetic variation and population structure of two species of fur seal (Arctocephalus gazella and A. tropicalis). Mol. Ecol. 9, 299-314. 